\title{
'Opportunity' and 'Enchantment' Wine Grapes for the Mid-South of the United States
}

\author{
John R. Clark ${ }^{1,5}$ and James N. Moore ${ }^{2,4}$ \\ Department of Horticulture, University of Arkansas, Fayetteville, AR 72701
}

Justin R. Morris ${ }^{2,4}$ and Renee Threlfall ${ }^{3}$

Food Science Department, University of Arkansas, Fayetteville, AR 72704

Additional index words. Vitis, fruit quality, fruit breeding, enology, cultivar

\begin{abstract}
'Opportunity' and 'Enchantment' wine grapes are new cultivars (Vitis hybrid) developed by the University of Arkansas System Division of Agriculture, the first wine grapes from the fruit breeding program. Both cultivars have shown good adaptation to the climate of Arkansas, resulting in production of quality wines. 'Opportunity' is a white wine grape, whereas 'Enchantment' is a red wine grape. These cultivars will be best used by grape growers and wine makers in the mid-South of the United States and will expand options for wine grape production in the region.
\end{abstract}

\section{Origin of Cultivars}

The grapevines, 'Enchantment' and 'Opportunity', were selected from a seedling vineyard located at the University of Arkansas Fruit Research Station (FRS), Clarksville, AR (West-Central Arkansas; lat. 35 $28^{\prime} 17^{\prime \prime} \mathrm{N}$, long. 93 $80^{\prime} 0^{\prime \prime}$; USDA hardiness zone 7a). Following selection, a single, own-rooted, three-vine plot of each cultivar was established on a fine sandy loam soil the year after selection. The cultivars were viticulturally evaluated by James N. Moore and John R. Clark through 1996 and then evaluated by Clark until the grapes were released in 2016.

'Opportunity' is a result of a cross of 'Cayuga White' $\times$ Ark. 1754 made in 1987 by Moore (Fig. 1). This white cultivar combines the female parent, 'Cayuga White' (from New York), which originated from Vitis labrusca L. and Vitis vinifera L. with the

Received for publication 27 Mar. 2018. Accepted for publication 7 May 2018.

Special thanks to David Gilmore, Effie Gilmore, Kay Buck, John Ridgeway, Dan Chapman, Sandra Sleezer, Kenda Woodburn, Gary Main, and Taunya Ernst for assistance in data collection in the evaluation of 'Opportunity' and 'Enchantment' wine grapes in Arkansas. Thanks to Bruce Reisch at New York Agricultural Experiment Station/ Cornell University for evaluation of 'Opportunity' and 'Enchantment' in New York.

${ }^{1}$ Distinguished Professor.

${ }^{2}$ Distinguished Professor Emeritus.

${ }^{3}$ Research Scientist.

${ }^{4}$ Deceased.

${ }^{5}$ Corresponding author. E-mail: jrclark@uark.edu.
Ark. 1754 parent which was a selection derived from the two $V$. vinifera cultivars, Semillon (thought to be from France) and Rkatsiteli (from the eastern European country of Georgia). The original plant was selected in 1991 and tested as selection Ark. 2245.

'Enchantment' resulted from a cross of Ark. $1628 \times$ Ark. 1481 made in 1990 by Moore (Fig. 2). This black cultivar combines multiple species. The female parent, Ark 1628 , resulted from a cross of two $V$. vinifera cultivars, 'Petit Sirah' and 'Alicante Bouschet'. The male parent, Ark. 1481, resulted from a cross of the $V$. vinifera-derived 'Bouschet Petit' and 'Salvador' ('Pate Noir'). 'Salvador' includes the species Vitis lincecumii (Buckley) Munson and Vitis rupestris Scheele from its 'Munson' parent. 'Enchantment' is a teinturier with black color in the flesh and juice of the grape. The original plant was selected in 1993 and tested as selection Ark. 2467.

\section{Vine Description and Performance}

The growth, yield, hardiness, and disease resistance of 'Opportunity' and 'Enchantment' were evaluated. Both subjective and objective evaluations of the cultivars' characteristics were conducted most years on 'Opportunity' from 1994 through 2015 and on 'Enchantment' from 1998 through 2015. Photographs of 'Opportunity' and 'Enchantment' at harvest are provided in Figs. 3 and 4. Berry and cluster characteristics were also evaluated before wine production.

Growth and yield. The vines were trained to a bilateral, high-cordon/curtain training system and pruned to three- to four-bud spurs annually. Vines were spaced $2.4 \mathrm{~m}$ and in rows of $3.1 \mathrm{~m}$. Weeds were controlled by applications of preemergence and postemergence herbicides annually. All vines received trickle irrigation as needed. Vines were fertilized annually in March or April with nitrogen or complete fertilizers. No cluster, shoot, or leaf removal practices were conducted on the vines. The subjective evaluations of the vines and fruit included cluster fill, crop, vigor, and health carried out each year using a scale of 1 to $10(1=$ very poor to $10=$ exceptional $/$ most desired). However, a 10 is not desired for cluster fill or vigor. A 10 rating represents a very tight cluster and excessive vigor, with a rating of 7 to 8 as more desirable for these attributes. In addition, objective data were collected for harvest date, berry weight (average of 25 berries per cultivar), cluster weight (average of five clusters), yield/vine, and composition for multiple years. The composition included soluble solids, $\mathrm{pH}$, and titratable acidity measured on juice extracted from a 25-berry sample. Yields were taken for 'Opportunity' for 1999-2003 and 2014 and for 'Enchantment' for 1999-2003, 2014, and 2015. Harvest date was determined primarily by juice soluble solids and $\mathrm{pH}$, with a target soluble solids of $20 \%$ and $\mathrm{pH}$ of 3.4 . Objective and subjective data are provided in Tables 1 and 2 .

Average harvest date for 'Opportunity' was 30 Aug. (day 242 of the year). Yield of 'Opportunity' averaged $10.9 \mathrm{~kg} / \mathrm{vine}$ $\left(14.6 \mathrm{t} \cdot \mathrm{ha}^{-1}\right)$ which is considered a good commercial yield for a wine grape in Arkansas (Table 1). Crop ratings averaged 7.7, a reflection of good crop, and consistent cropping was seen in most years (Table 2). Cluster weight averaged $234.3 \mathrm{~g}$. Clusters were rated very full (10 on a 1 to 10 scale) with berries attached very tightly. Berry weight averaged $2.7 \mathrm{~g}$. Fruit cracking was not observed for 'Opportunity' following summer rains near harvest. Rating for vigor averaged 7.2, reflecting medium-high, but not excessive, vigor. Health of the vines was consistently rated good (averaging 7.4). Magnesium chlorosis symptoms were observed in some years, but did not appear to affect vine performance. In terms of berry and cluster characteristics before wine production, it was noted that 'Opportunity' had medium-sized berries with large, tight clusters, and some sun burn in a limited number of years.

Average harvest date for 'Enchantment' was 22 Aug. (day 234 of the year), with yields averaging $10.1 \mathrm{~kg} /$ vine $\left(13.6 \mathrm{t} \cdot \mathrm{ha}^{-1}\right)$ (Table 1). Crop rating averaged 7.7, reflecting good cropping consistency and potential (Table 2). Berry weight averaged $1.5 \mathrm{~g}$, whereas clusters averaged 178.3 g. Cluster fill was rated 9.0,

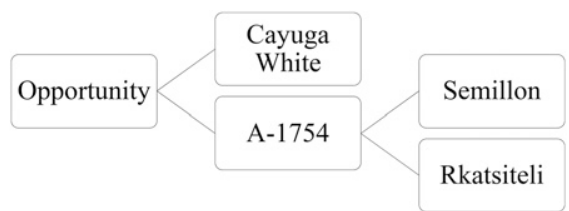

Fig. 1. Pedigree of 'Opportunity' grapevine.

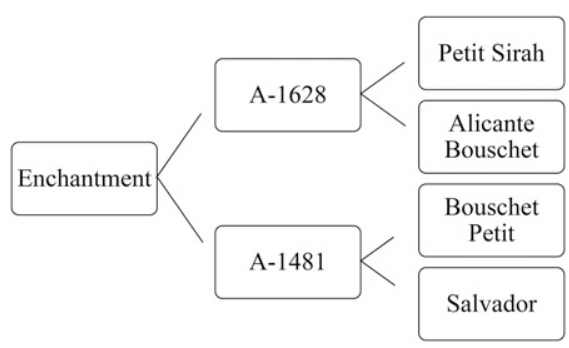

Fig. 2. Pedigree of 'Enchantment' grapevine. 
indicating a compact cluster but not as tight compared with 'Opportunity'. Fruit cracking following summer rains near harvest was not observed for 'Enchantment'. Rating for vigor averaged 6.7 , indicating moderate vigor (Table 2). Health of the vines was consistently rated good (averaging 7.1). Leaves were often noted to be paler in green color than other cultivars and selections in the research vineyard, but this appearance did not appear to affect vine performance. In terms of berry and cluster characteristics before wine production, it was noted that 'Enchantment' had mediumsized berries with large, semi-loose clusters.

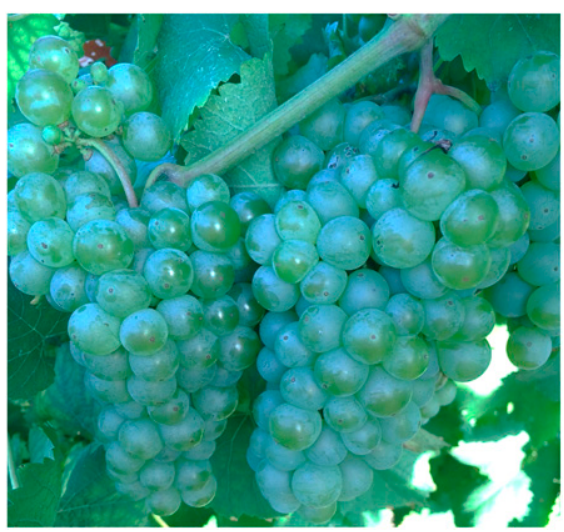

Fig. 3. Photograph of clusters of 'Opportunity' white wine grape at maturity.

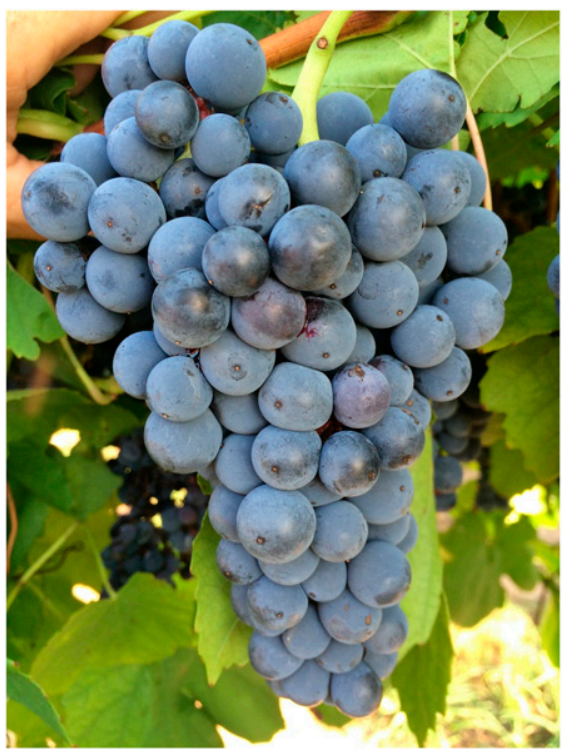

Fig. 4. Photograph of a cluster of 'Enchantment' red wine grape at maturity.
Winter and summer hardiness. Winter injury observations were made at fruit maturity each year. During the evaluation of these cultivars, the winter low temperatures ranged from $-17{ }^{\circ} \mathrm{C}$ (Winters of 1996, 1997, and 2011) to $-9{ }^{\circ} \mathrm{C}$ (Winter of 2008). The cultivars survived these winter lows with no to minimal winter damage. The adaptation of 'Opportunity' and 'Enchantment' to the climate at FRS was very good and reflective of potential for reliable production in the mid-South of the United States. Winter injury was not observed during testing, reflecting good hardiness for this location. However, the late spring freeze of 2007, which occurred after shoots were extended $\approx 0.5 \mathrm{~m}$, contributed to cordon injury of 'Enchantment' in addition to shoot damage.

Vines of each cultivar were also sent to the New York State Agricultural Experiment Station, Geneva, NY, in 2002 for evaluation of cold hardiness. In testing in New York, 'Opportunity' had five of six vines surviving by 2006 and 'Enchantment' had two of five vines surviving by 2006 . Surviving vines of both cultivars had bud and trunk damage in the Winters of 2003-04 and 2004-05 where winter minima were below $-23{ }^{\circ} \mathrm{C}$. Late ripening in New York was noted as a limitation for these cultivars in this shorter season climate.

Disease resistance. The vines were grown in a research vineyard with an integrated pest management approach and a minimal spray program to allow for the evaluation of resistance to pests and diseases. Fungicides were applied similar to a commercial requirement to control black rot (Guignardia bidwellii Viala \& Ravaz), powdery mildew [Erysiphe necator Schw. (syns. Uncinula necator (Schw.) Burr., Erysiphe tuckeri Berk., Uncinula americana Howe, and Uncinula spiralis Berk. \& Curt; anamorph Oidium tuckeri Berk.], downy mildew (Plasmopara viticola Berl. \& de Toni), and anthracnose (Elsinö̈ ampelina Shear) in seedling and selection plantings. However, the last application of any fungicide was usually carried out near the end of June to early July, 7-8 weeks before harvest of wine grapes. This extended period from the last spray until harvest resulted from the vines being grown in a vineyard with earlier ripening grape selections and cultivars, and preharvest intervals prevented continued spray applications after late June to early July. This resulted in increased disease pressure on the wine grape cultivars because of the long interval from last spray application until harvest. Insecticides were applied as needed to control climbing cutworm (several species common including Agrotis ipsilon Hufnagel, Feltia jaculifera Guenée, and Peridroma saucia Hübner) and grape berry moth (Paralobesia viteana Clemens). No control near harvest was conducted for spotted wing drosophila (Drosophila suzukii Matsumura) and no damage from this insect was observed.

Examination for the presence of diseases was carried out for the vines of each cultivar. Some rotting of berries was observed in some years, particularly near harvest. This is likely due to the extended period since the last fungicide spray was applied. For 'Opportunity', the tight cluster architecture can contribute to bunch rot, so careful control of rot near harvest will need to be undertaken to ensure disease-free fruit. By contrast, in the very dry and hot Summer of 2012, no fruit rot in 'Opportunity' was noted.

In over 20 years of observation of ' $\mathrm{Op}$ portunity', powdery mildew was seen on leaves in 2 years, including only slight leaf infection in the very severe powdery mildew year of 2015. Downy mildew was not observed on 'Opportunity', even in the severe infection year of 2013 when this disease was very common in the research vineyard. In 18 years of observation of 'Enchantment', powdery mildew was seen on leaves in 2 years and on fruit in the severe powdery mildew year of 2015. Downy mildew was observed 1 year on 'Enchantment' vines with a slight infection on leaves. Neither black rot nor anthracnose was noted on the vines, but these earlier season diseases were likely controlled by fungicide applications and no resistance is implied for these. It is hoped that the minimal observation of common diseases reflects the potential to manage disease pressures with average or possibly slightly reduced applications of fungicides/pesticides.

\section{Fruit and Wine Quality}

The fruit and wine quality of 'Opportunity' and 'Enchantment' were evaluated. Before harvest, grapes were monitored for maturity using visual and field chemistry analysis. Juice samples from grape berries in the field were measured with a handheld digital refractometer to estimate soluble solids (expressed as \%) and with other refractometers for laboratory analysis. Titratable acidity (expressed as $\mathrm{g} / 100 \mathrm{~mL}$ tartaric acid) and $\mathrm{pH}$ were also measured analytically. Sugars and acids of juice from the grapes and sugar, acids, and ethanol of wine

Table 1. Objective data for 'Opportunity' (plot established 1992) and 'Enchantment' (plot established 1994) wine grapes on three-vine plots, University of Arkansas Fruit Research Station, Clarksville, AR. Data are from various years, 1999-2015.

\begin{tabular}{|c|c|c|c|c|c|c|c|}
\hline$\overline{\text { Cultivar }}$ & Harvest date & Yield/vine (kg/vine) & Cluster wt (g) & Berry wt (g) & Soluble solids (\%) & $\mathrm{pH}$ & Titratable acidity $(\mathrm{g} / 100 \mathrm{~mL})^{\mathrm{z}}$ \\
\hline Opportunity & 2 Sept. $(17.8)^{\mathrm{y}}$ & $10.9(7.5)^{x}$ & $234.3(125.5)^{\mathrm{y}}$ & $2.7(0.3)^{y}$ & $17.3(2.1)^{y}$ & $3.5(0.3)^{y}$ & $0.5(0.0)^{\mathrm{y}}$ \\
\hline Enchantment & 22 Aug. $(8.4)^{\mathrm{w}}$ & $10.1(5.9)^{\mathrm{w}}$ & $178.3(30.9)^{\mathrm{w}}$ & $1.5(0.2)^{\mathrm{w}}$ & $18.9(2.1)^{\mathrm{w}}$ & $3.4(0.1)^{\mathrm{w}}$ & $0.8(0.1)^{\mathrm{w}}$ \\
\hline
\end{tabular}

${ }^{\mathrm{z}}$ Measured as tartaric acid.

${ }^{\mathrm{y}}$ Means and SDs (in parentheses) 1999-2001, 2003, 2014, and 2015.

${ }^{\mathrm{x}}$ Means and SDs (in parentheses) 1999-2001, 2003, and 2014.

${ }^{\mathrm{w}}$ Means and SDs (in parentheses) 1999-2003, 2014, and 2015. 
were measured by high performance liquid chromatography (HPLC). Sugars and acids measured by HPLC were expressed as $\mathrm{g} / \mathrm{L}$, and ethanol was expressed as \% v/v. Because the analysis was carried out over 25 years, the equipment used varied. A grape and wine industry-based expert panel was used for sensory evaluation.

Berry composition and quality. The grape berry composition was evaluated at harvest and before wine production. Juice composition at harvest was evaluated on fruit at FRS (Table 1). For 'Opportunity', juice $\mathrm{pH}$ averaged 3.5, titratable acidity averaged $0.5 \mathrm{~g} / 100$ $\mathrm{mL}$, and soluble solids averaged $17.3 \%$. For 'Enchantment', juice $\mathrm{pH}$ averaged 3.4, titratable acidity averaged $0.8 \mathrm{~g} / 100 \mathrm{~mL}$, and soluble solids averaged $18.9 \%$. Both cultivars had good titratable acidity and $\mathrm{pH}$ levels at harvest for production of wine.

The soluble solids, $\mathrm{pH}$, and titratable acidity of the juice were also determined before winemaking, as well as berry tasting notes. Juice/must analyses of 'Opportunity' and 'Enchantment' were compared with other cultivars grown at FRS in various years from 1995 to 2005 (Tables 3 and 4). 'Opportunity' had $17.3 \%$ soluble solids, $3.4 \mathrm{pH}$, and $0.52 \mathrm{~g} / 100 \mathrm{~mL}$ titratable acidity. 'Enchantment' had $19.5 \%$ soluble solids, $3.5 \mathrm{pH}$, and $0.83 \mathrm{~g} / 100 \mathrm{~mL}$ titratable acidity. Both 'Opportunity' and 'Enchantment' had comparable composition to other cultivars grown in this area of the United States. It should be noted here that there are not many black cultivars that grow well in this zone, and 'Enchantment' can fill that gap in production. In terms of the berry taste, it was noted that 'Opportunity' had neutral-flavored juice with bitter skins and seeds, and 'Enchantment' had deep-colored berries, low acid taste, cherry-like aroma, and color with occasional mention of herbaceous flavor.

Wine production. Wines were made from the grapes since 1995 for 'Opportunity' and 1998 for 'Enchantment' through 2015 using a standard protocol for microvinification. Grapes of both cultivars were handharvested and delivered to the Food Science Department, University of Arkansas, Fayetteville. The amount of fruit processed ranged from 15 to $50 \mathrm{~kg}$ per cultivar. The grapes were stored overnight at $2{ }^{\circ} \mathrm{C}$, removed from cold storage, crushed, and destemmed, and the must (juice, seeds, and skins) was placed in a food grade container. Sulfur dioxide (as potassium metabisulfite) was typically added at crush at a rate of $30 \mathrm{mg} / \mathrm{L}$. Yield at crush was $\approx 3.8 \mathrm{~L}$ of juice/must for $7 \mathrm{~kg}$ of 'Opportunity' and for $4.9 \mathrm{~kg}$ for 'Enchantment'. Opportunity was processed in a traditional white wine style, so the must was pressed, and then the juice was fermented. 'Enchantment' was processed in a traditional red-wine style with the must placed in a fermentation vessel, and then fermented

Table 2. Subjective data (scale of $1=$ very poor; $10=$ exceptional) for 'Opportunity' (plot established 1991) and 'Enchantment' (plot established 1994) wine grapes in three-vine plots, University of Arkansas Fruit Research Station, Clarksville, AR. Data are from various years, 1999-2015.

\begin{tabular}{lcccc}
\hline Cultivar & Cluster fill & Crop & Vigor & Health \\
\hline Opportunity & $10.0(0.0)^{\mathrm{z}}$ & $7.7(1.4)^{\mathrm{y}}$ & $7.2(0.8)^{\mathrm{y}}$ & $7.4(0.9)^{\mathrm{y}}$ \\
Enchantment & $9.0(0.8)^{\mathrm{x}}$ & $7.7(1.7)^{\mathrm{w}}$ & $6.7(0.7)^{\mathrm{w}}$ & $7.1(0.7)^{\mathrm{w}}$ \\
\hline
\end{tabular}

${ }^{\mathrm{z}}$ Means and SDs (in parentheses) 1994-2002, 2004, 2005, 2008, and 2010.

${ }^{\mathrm{y}}$ Means and sDs (in parentheses) 1994-2002 and 2004-2015.

${ }^{\mathrm{x}}$ Means and SDs (in parentheses) 1998-2002, 2004, 2005, and 2015.

${ }^{\mathrm{w}}$ Means and sDs (in parentheses) 1997-2002 and 2004-2015.

2-7 d on the skins. Before fermentation, the initial composition (soluble solids, $\mathrm{pH}$, and titratable acidity) of the juice/must were evaluated and adjustments were performed as needed to achieve a $\mathrm{pH}$ less than 3.5 , titratable acidity of $0.7 \mathrm{~g} / 100 \mathrm{~mL}$, and soluble solids of $20 \%$ to $22 \%$. Must/wine was pressed in a \#25 Enorossi stainless steel bladder press (Enoagricola Rossi s.r.l., Calzolaro, Italy) and collected in glass carboys. Juice for 'Opportunity' was cold settled at $2{ }^{\circ} \mathrm{C}$, racked, and adjusted before fermentation. Must for 'Enchantment' was fermented after crushing. Wines were inoculated with commercial active dried yeast (Lallemand, Inc., Montreal, Canada) and fermented at 15 to $21{ }^{\circ} \mathrm{C}$. The fermented wine was racked several times during fermentation to remove spent yeast cells and prevent the production of off flavors. After completion of fermentation $(<0.5 \%$ residual sugar), sulfur dioxide was added as potassium metabisulfite to prevent oxidation and spoilage. White wines were cold stabilized. Wines were bottled in 375 $750 \mathrm{~mL}$ glass bottles with screw caps or corks and stored at $15^{\circ} \mathrm{C}$.

Wine composition and quality. After fermentation, the composition of the wine was measured. The amount of ethanol and acids in the wines varied by year and depended on the adjustments made for wine production. Wine quality of 'Opportunity' and 'Enchantment' was consistently good as reflected by various measurements of composition (Tables 3 and 4). In 2001, a wine-tasting evaluation was hosted for representatives of the commercial Arkansas grape and wine industry, and the panel had positive impressions of wines from both cultivars.

Wines of 'Opportunity' were compared with 'Chardonel', 'Symphony', 'Verdelho', and 'Viognier' also from FRS. For 'Opportunity' wine production, sugar additions were

Table 3. Juice and wine analyses of 'Opportunity' and four other white wine grape cultivars grown at the University of Arkansas Fruit Research Station, Clarksville, AR.

\begin{tabular}{|c|c|c|c|c|c|c|c|c|}
\hline \multirow[b]{2}{*}{ Cultivar } & \multicolumn{3}{|c|}{ Juice $^{z}$} & \multicolumn{5}{|c|}{ Wine $^{y}$} \\
\hline & $\begin{array}{c}\text { Soluble } \\
\text { solids (\%) }\end{array}$ & $\mathrm{pH}$ & $\begin{array}{c}\text { Titratable acidity } \\
(\mathrm{g} / 100 \mathrm{~mL})^{\mathrm{z}}\end{array}$ & $\mathrm{pH}$ & $\begin{array}{l}\text { Titratable acidity } \\
(\mathrm{g} / 100 \mathrm{~mL})^{\mathrm{x}}\end{array}$ & Ethanol $(\% \mathrm{v} / \mathrm{v})$ & $\begin{array}{c}\text { Tartaric } \\
\text { acid }(\mathrm{g} / \mathrm{L})\end{array}$ & $\begin{array}{c}\text { Malic } \\
\text { acid }(\mathrm{g} / \mathrm{L})\end{array}$ \\
\hline Opportunity & 17.3 & 3.4 & 0.52 & 3.0 & 0.66 & 12.12 & 3.18 & 1.80 \\
\hline Verdelho & 20.3 & 3.4 & 0.53 & 3.1 & 0.74 & 13.30 & 3.40 & 2.40 \\
\hline Viognier & 20.0 & 3.6 & 0.45 & 3.2 & 0.64 & 13.00 & 2.10 & 3.20 \\
\hline
\end{tabular}

${ }^{\mathrm{z}}$ Means of 'Opportunity' juice were from 1995 to 2001 and 2003 and means of other cultivars were from 2001.

${ }^{\mathrm{y}}$ Means of 'Opportunity' wine were from 1995 to 2001 and means of other cultivars were from 2001.

${ }^{\mathrm{x}}$ Measured as tartaric acid.

Table 4. Juice and wine analyses of 'Enchantment' and 'Cynthiana' red wine grape cultivars grown at the University of Arkansas Fruit Research Station, Clarksville, AR.

\begin{tabular}{|c|c|c|c|c|c|c|c|c|c|}
\hline \multirow[b]{2}{*}{ Cultivar } & \multicolumn{3}{|c|}{ Juice $^{z}$} & \multicolumn{6}{|c|}{ Wine $^{\mathrm{y}}$} \\
\hline & $\begin{array}{l}\text { Soluble } \\
\text { solids (\%) }\end{array}$ & $\mathrm{pH}$ & $\begin{array}{c}\text { Titratable } \\
\text { acidity }(\mathrm{g} / 100 \mathrm{~mL})^{z}\end{array}$ & $\mathrm{pH}$ & $\begin{array}{l}\text { Titratable acidity } \\
\quad(\mathrm{g} / 100 \mathrm{~mL})^{\mathrm{x}}\end{array}$ & Ethanol $(\% \mathrm{v} / \mathrm{v})$ & $\begin{array}{l}\text { Tartaric acid } \\
(\mathrm{g} / \mathrm{L})\end{array}$ & $\begin{array}{l}\text { Malic acid } \\
(\mathrm{g} / \mathrm{L})\end{array}$ & $\begin{array}{l}\text { Lactic acid } \\
\qquad(\mathrm{g} / \mathrm{L})\end{array}$ \\
\hline Enchantment & 19.5 & 3.5 & 0.83 & 3.4 & 0.86 & 11.24 & 4.34 & 1.28 & 1.40 \\
\hline Cynthiana & 22.7 & 3.5 & 1.12 & 3.6 & 0.81 & 11.20 & 3.70 & 1.60 & 3.70 \\
\hline
\end{tabular}

'Means of 'Enchantment' juice were from 1998 to 2003 and 2005 and means of 'Cynthiana' were from 2001.

${ }^{\mathrm{y}}$ Means of 'Enchantment' wine were from 1999 to 2001 and means of 'Cynthiana' were from 2001.

${ }^{\mathrm{x}}$ Measured as tartaric acid. 
needed most years and acid additions some years. Wines produced from 'Opportunity' had a $3.0 \mathrm{pH}, 0.66 \mathrm{~g} / 100 \mathrm{~mL}$ titratable acidity, $12.12 \%$ ethanol, $3.18 \mathrm{~g} / \mathrm{L}$ tartaric acid, and $1.80 \mathrm{~g} / \mathrm{L}$ malic acid. 'Opportunity' wine made in 2015 was evaluated for color with a $L^{*}$ value $=64.44, a=-0.78, b=12.65$, and color density $(420 / 520)=1.56$. During the wine tasting, 'Opportunity' wine was noted for distinct fruit flavors, honey aroma, and a light gold color. The wines had spicelike 'Semillon' and bouquet of 'Cayuga White'. The only negative comment concerned the ability of 'Opportunity' to compete with established white wine cultivars adapted in Arkansas such as 'Seyval', 'Cayuga White', and 'Chardonel'. It is hoped that 'Opportunity' will complement other cultivars in commercial production in Arkansas and other regions with similar growing conditions. 'Opportunity' can be used to produce a single varietal wine or be used as a blender to enhance flavor or aroma of other wines.

'Enchantment' was compared with 'Cynthiana'. For 'Enchantment' wine production, sugar additions were needed some years and acid additions most years. Wines produced from 'Enchantment' had a $3.4 \mathrm{pH}, 0.86 \mathrm{~g} / 100$ $\mathrm{mL}$ titratable acidity, $11.24 \%$ ethanol, 4.34 $\mathrm{g} / \mathrm{L}$ tartaric acid, $1.28 \mathrm{~g} / \mathrm{L}$ malic acid, and $1.4 \mathrm{~g} / \mathrm{L}$ lactic acid. Malvidin-3-glucoside was identified as the primary anthocyanin in 'Enchantment'. 'Enchantment' wine made in 2015 was evaluated for color with a $L^{*}$ value $=1.44, a=1.30, b=-0.32$, and color density $(420 / 520)=6.39$. In the wine tasting, the deep, red color of 'Enchantment' was noted, along with a good fruit aroma similar to 'Syrah'. Some vegetal characters were noted, but in general there were no negative comments regarding 'Enchantment'. 'Enchantment' can be used to produce a single varietal wine or be used as a blender to enhance the color or flavor of other wines. In addition, because the major anthocyanin is malvidin-3-glucoside, the wine is expected to perform well if aged in the bottle or in oak cooperage.

\section{Availability}

The University of Arkansas has filed an application for a U.S. plant patent on 'Opportunity' and 'Enchantment' grapevines. Nurseries interested in propagating these cultivars must sign a license agreement with the University of Arkansas System Division of Agriculture Technology Commercialization Office (https://technologycommercialization.uark.edu/about.aspx). Contact the Technology Commercialization Office for a list of licensees or to inquire about propagation of 'Opportunity' and 'Enchantment' grapevines. 